\title{
"A hazai betegtájékoztatás XXI. századi elvárásai - a tájékoztatáshoz való jog megvalósulásának vizsgálata a felnőtt háziorvosi alapellátásban (kérdőíves felmérés eredményeivel)"
}

\section{" Expectations for 21st century patient information in Hungary - examining the right to being informed in general practice only for adults (including the outcomes of a survey questionnaire)"}

Lengyel Ingrid betegjogi képviselö, doktorandusz

Emberi Erőforrások Minisztériuma - Integrált Jogvédelmi Szolgálat, Semmelweis Egyetem 4/2. Doktori Iskola

lengyel.ingrid@gmail.com

Initially submitted March 18, 2020; accepted for publication Apr.28, 2020

\begin{abstract}
Background: the survey questionnaire was designed to show the patterns of patient information in adult general practice in Hungary, based on the patients' feedback. The outcomes of patient information were examined in detail; health literacy was not investigated in this study.

Aims: the study compares above all the contents of concerning legislation with outcomes of the survey (2017-2019)

Method: The survey was done in a adult sample $(\mathrm{N}=547)$ by a questionnaire containing 42 questions in 5 chapters.

Results: concerning patient information, various deviations from the legal requirements were observed.

Conclusions: further results of the study show that besides the legislative framework defining patient information, in general practitioners' offices doctor-patient interactions are essential.
\end{abstract}

Kulcsszavak: betegtájékoztatás, orvos-beteg interakciók, egészségi állapot, tanácsadás

Keywords: patient information, doctor-patient interactions, health status, counselling

\section{Introduction}

Informing patients is still a concern for both patients and doctors. Subsection (1) of section 45 of Act II. of 1972 was the first to deal with general patient information. The current healthcare law (ACT CLIV of 1997) specifies and details nine patient rights. According to these legal statutes, the patient must rightfully receive full information in an individualized manner. Regarding the extent and length of patient information, its primary aim should be observed and considered, which is to enable the patient to make an informed decision after having obtained all necessary information and having considered whether to provide their consent to proceed with the intervention. Thus, they can exercise their right to selfdetermination. Patient information can only be considered as legitimate if it provides the means for this. Patients therefore need to be brought into a position where they can evaluate the risk of intervention and be able to make an informed decision about their own fate.

\section{Examining the implementation of the right to information in adult primary general practice}

The efficiency of healthcare systems can be significantly improved if people are able to navigate within them, thus seeking out the appropriate doctors at the appropriate times, being diagnosed in time, so 
Kaleidoscope Müvelődés-, Tudomány- és Orvostörténeti Folyóirat Journal of History of Culture, Science and Medicine
2020. Vol. 10. No. 20.

e-ISSN: 2062-2597

DOI: $\underline{10.17107 / \mathrm{KH} .2020 .20 .190-195}$

that their therapy can begin before more expensive interventions would become necessary. In addition, they will understand the treatment methods of chronic illnesses and follow the therapeutic guidelines. By choosing the right lifestyle, some illnesses can even be prevented. This type of health-conscious behaviour, health literacy, can significantly improve the efficiency of the healthcare system and contribute to a better health status of Hungarian citizens.

The legal requirements of patient information are set out in section 13 Act CLIV. of 1997. If the service provider of the Hungarian healthcare system were to pay strict attention and ample time to all paragraphs, the entire system would become inoperable. Thus, a sufficient bridging solution could be to provide the patient with a minimum amount of information, focusing on the patient's condition, observing short-term goals and planned procedures and therapies. The law - amongst others - declares that:

'The patient is entitled to complete information provided in a personalised form.

(2) The patient shall have the right to receive detailed information, in addition to information related to the processing of their personal data,

a) their state of health, including its medical evaluation, b) the proposed tests, interventions,

c) the potential benefits and risks of performing or failing to perform the proposed tests, interventions,

d) the planned dates of the examinations and interventions,

e) decision-making power in relation to the proposed investigations, interventions, f) possible alternative procedures, methods,

g) the process and expected outcome of the care, h) other services; and

i) the recommended lifestyle.

(3) The patient shall have the right to ask further questions during and after the briefing. The patient shall have the right to be informed in a manner which is comprehensible to him or her, having regard to his or her age, education, knowledge, state of mind, wish expressed in this regard and the provision of an interpreter or sign language interpreter if necessary and possible...' [1]

However, the interpersonal characteristics of the physician-patient relationship are not regulated or influenced by uniform and internationally accepted principles, as new scientific findings guide diagnostics or applied therapies. Socio-cultural influences, often differing habits, values, and professional traditions often influence the development of a doctor's or patient's moral attitudes more deeply than the principles matured in medical ethics debates. As a result, the adoption of new standards on patient information is not uniform in Hungarian medical practice.

Violation of the right to information, according to statistics compiled by the Integrated Legal Service in 2018 , accounts for $6 \%(4,748)$ of the annual requests for patient rights representatives. 
Kaleido scope
Journal of History of Culture, Science and
Judodicine

DOI: $\underline{10.17107 / K H .2020 .20 .190-195}$

\begin{tabular}{|c|c|}
\hline Year & Number of referrals \\
\hline 2013 & 9959 \\
\hline 2014 & 12198 \\
\hline 2015 & 14080 \\
\hline 2016 & 14183 \\
\hline 2017 & 14622 \\
\hline 2018 & 14102 \\
\hline Total: & 79144 \\
\hline Table 1: Numbers of patient law representative referrals (2013-2018)
\end{tabular}

The awareness of patients' rights among patients and their relatives was outstanding in the capital. [2] In primary care, 3768 people (28\%) sought their patient rights representatives. This was the lowest number of requests by type of service provider.

In most cases, patients did not receive individualised and whole information. Another commonly occurring incident was that during the provision of information, or afterwards, patients still did not dare to ask further questions related to the information session. Among the requests for patient rights representatives, the violation of the right to information seldom featured alone. In most cases, it was somehow connected or coupled with complaints related to other patients' rights. In many cases, the patient rights representatives observed that the number of non-medical complaints could have been significantly reduced if the communication within the doctor/nurse - patient relationship of trust were to improve. [3] The cases in which the patient does not receive ample guidance and information indirectly influences the patient's health status, in some cases indicating the need for more healthcare services.

Gaps in patient information of service providers are common [4], but neither the care nor the funding system helps or encourages the physician to explain the disease, the options, and the possible complications to information-hungry patients in sufficient detail. Without proper (funded) time, this is usually not feasible. Judicial jurisprudence, on the other hand, has consistently ruled on claims for failure to provide "complete" information. Even with signed

patient information and patient consent statements, it is very difficult for service providers to prove that the patient could have asked any "additional" questions during the "personalised" oral information exchange. This would require the actual details of the doctor-patient communication to be reflected in the signed patient-consent statement (we should consider recording such sessions). As a result, physicians are becoming documenting "machines" that look at the screen (and not at the patient). Meanwhile, the growing number of patients waiting and funding constraints are opposite to the above demands. [5].

Presentation of the main research results 
Only those research results are presented that have shown some relevance to the topic of patient information. According to the types of questions that appeared in the thematic block, they included an even-numbered Likert scale (1), an odd-numbered Likert scale (3), multiple-choice (Y/N) type questions (4) and multiple-choice questions (7).

If the GP sends a patient for further examination, $80.3 \%$ of the respondents are informed about the reasons, while $19.7 \%$ are not or do not ask questions at all. It is interesting that $66 \%$ of the respondents receive information about the date and time of the planned examinations, while $34 \%$ do not receive such information. This leads to the assumption that the GP puts an lot of emphasis on following the patient's path. However, the evidentiary nature of seeking consent to conduct investigations and interventions can be questioned; the researcher assumes the patient's trust in the doctor in this question.

\begin{tabular}{|l|c|c|c|}
\hline Reason & $\begin{array}{c}\text { Respondents } \\
\text { number } \\
\text { (person) }\end{array}$ & Ratio (\%) & $\begin{array}{c}\text { Ratio of valid } \\
\text { responses (\%) }\end{array}$ \\
\hline $\begin{array}{l}\text { The patient cannot decide } \\
\begin{array}{l}\text { The doctor does not accept the } \\
\text { patient's - possibly wrong - decision }\end{array}\end{array}$ & 68 & 12.4 & 21.9 \\
\hline $\begin{array}{l}\text { The doctor does not have time for } \\
\text { this }\end{array}$ & 101 & 14.3 & 25.1 \\
\hline $\begin{array}{l}\text { Only the doctor can decide on } \\
\text { examinations and interventions }\end{array}$ & 64 & 11.7 & 20.6 \\
\hline $\begin{array}{l}\text { All valid responses } \\
\text { Did not answer }\end{array}$ & 311 & 56.9 & 100.0 \\
\hline Total & 236 & 43.1 & \\
\hline
\end{tabular}

Table 2. If your doctor does not ask for your consent to the examinations and interventions, what do you think the reason is?

The questionnaire also addressed whether the patient would receive lifestyle advice. 59\% of the respondents $(n=535)$ did not, $41 \%$ did. The question may be how this situation may be improved, as cardiovascular and cancer-related deaths in the Hungarian population are closely related to lifestyle differences. It is interesting that only $11.5 \%(n=63)$ of the respondents pay attention to lifestyle advice in any way.

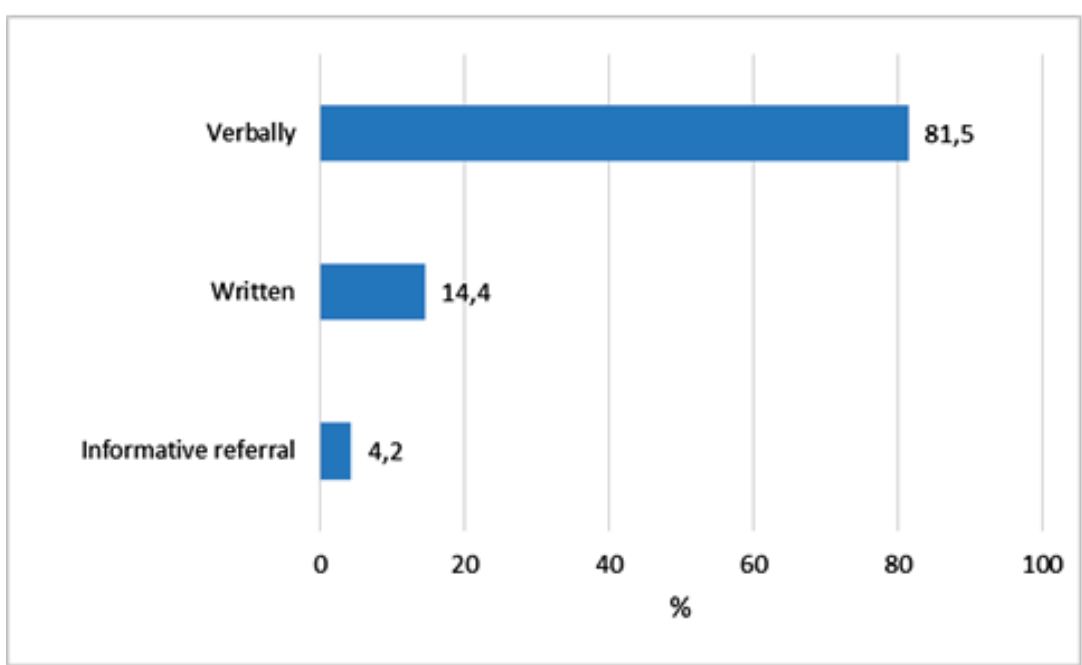

http://www.kaleidoscopehistory.hu

Lengyel Ingrid doktorandusz 
Kaleidoscope
Journal of History of Culture, Science and Medicine

DOI: $\underline{10.17107 / K H .2020 .20 .190-195}$

Table 3. How does your GP inform you about your illnesses? $(n=101)$

In the case of written information, this meant a hand-written description from the doctor, or them handing over a flyer or other advertising material. An informative referral refers to a website, link, or magazine recommendati

Examining patient pathway control, we also asked how the patient was informed about his or her examination results. $66.3 \%$ of the respondents $(n=513)$ were rescheduled for another appointment, $16.6 \%$ inquired over the phone, the results were given to the relatives of $4.3 \%$, and $8.4 \%$ were emailed the test result. $4.5 \%$ of respondents were unaware of their results. The results raise questions about data protection, GDPR requirements, and authorisation issues, however, this was not part of the study.

During the study, a significant role was given to the data that informed us about how respondents were trying to find out more about their illness, medicines, and other health issues.

Respondents generally preferred the wide range of information available on the Internet. This correlates with age data; $68.3 \%$ of the respondents $(n=547)$ are between the age of 18 and 45 and are considered active Internet users.

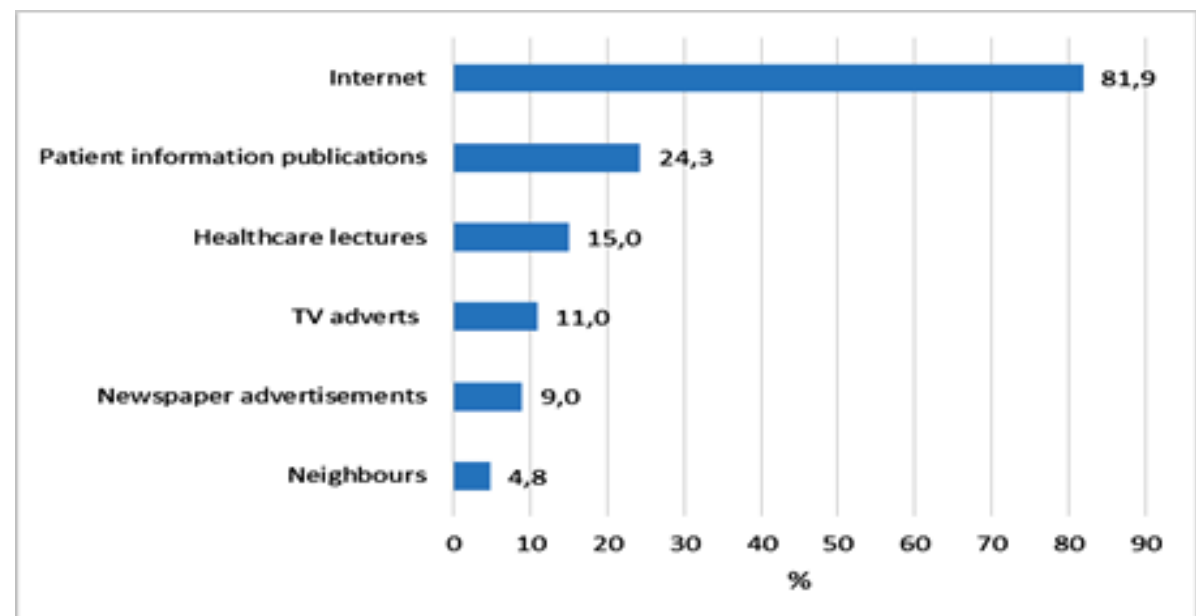

Table 4: What other places do you seek out to learn about your illness, medication, and other health issues? (n=535)

\section{Conclusions:}

Patient information should always be specific to the individual case, also considering the principles of graduality and health literacy. Among the content elements, it is recommended to provide the most possible options as possibleto meet legal requirements, and to enable the patient to formulate questions, and to let the well-informed patient make decisionsregarding their health and condition. The requirements set out in the legislation are only partially met in primary general practice care.

\section{1st century expectations for Hungarian patient information (in the light of research)}

A well-informed patient has different attitudes towards healthcare, possible system failures (waiting times being too long, lack of specialists, etc.). It also has a significant impact on the effectiveness of the therapy being applied and, consequently, on the healing process. 
Kaleidoscope Művelődés-, Tudomány- és Orvostörténeti Folyóirat Journal of History of Culture, Science and Medicine
2020. Vol. 10. No. 20.

e-ISSN: 2062-2597

DOI: $\underline{10.17107 / \mathrm{KH} .2020 .20 .190-195}$

Most patients do not sue doctors for financial gain. There is no money that could make up for a loss or a tragedy. Very often, hospitals and doctors immediately become defensive, apologetic, giving no explanation, and showing no signs of learning anything from the case. Patients sue because they do not get answers. They feel that their doctors have left them alone. They lack human treatment and compassion. [6]

The results of the research highlighted that patients want more information, and that they believe and trust their doctors and caretakers. If they do not receive sufficient and comprehensible information about their illness or condition, they will seek information from other forums, and this may not always be effective. The so-called "simple consent" for medical interventions is a feature of the traditional, paternalistic doctor-patient relationship [7], which model is still typical in Hungarian medicine.

\section{References:}

[1] Az egészségügyről szóló 1997.évi CLIV.törvény 13.§-a http://net.jogtar.hu (hatályos: 2020.február 10.) [Healthcare Law]

[2] Annual activity report of National Centre for Patients' Rights and Documentation of 2018. [IJSZ, 2018.évi szakmai beszámoló.] http://www.ijsz.hu/UserFiles/beszamolo_2018.pdf [Hungarian] 25.p (Downloaded: 7 February 2020.)

[3] Annual activity report of National Centre for Patients' Rights and Documentation of 2018. [IJSZ, 2018.évi szakmai beszámoló.] http://www.ijsz.hu/UserFiles/beszamolo_2018.pdf [Hungarian] 29.p (Downloaded: 7 February 2020.)

[4] Annual activity report of National Centre for Patients' Rights and Documentation of 2014.[OBDK,2014.évi szakmai beszámoló.] http://www.obdk.hu/UserFiles/beszamolo_2014.pdf (Downloaded: 7 February 2020.)

[5] Case Law/ Esetjog: 2229 Civil Principal Decision of the Supreme Court of 2010. [A Legfelsőbb Bíróság 2229/2010. számú polgári elvi határozata (EBH2010. 2229.)] http://www.kuriabirosag.hu/hu/elvhat/22292010-szamu-polgari-elvi-hatarozat $\quad$ Pfv. III.

21.318/2008 Decision of the Supreme Court of 2010. [A Legfelsőbb Bíróság Pfv. III. 21.318/2008. számú polgári jogi döntése (BH2010. 65.)] http://www.petrassydr.hu/images/ stories/BH2010.65.pdf 1867 Civil Principal Decision of the Supreme Court of 2008. [A Legfelsőbb Bíróság 1867/2008. számú polgári elvi határozata (EBH2008. 1867.)] http://www.hqsoft.eu/k/images/stories/ EBH2008.1867.pdf [Hungarian]

[6] Dr. Robin Youngson: Együttérző gyógyítás - Szemléletváltás az orvoslásban [Compassionate medicine - A change of mindset in medicine] HVG Könyvek, Budapest, 2017. P: 66-68.

[7] Dr. Kovács József: A modern orvosi etika alapjai (Bevezetés a bioetikába) [Fundamentals of Modern Medical Ethics (Introduction to Bioethics)], Medicina Könyvkiadó Zrt., Budapest, 2006. P: 127. 